\title{
Out of School Children in Rural Areas of Punjab: An Exploratory Study
}

\author{
* Dr. Shahzada Qaisar, Associate Professor \\ ** Dr. Intzar Hussain Butt, Associate Professor \\ *** Dr. Maria Shiraz, Assistant Professor
}

\begin{abstract}
The main aim of the study was to explore the causes of miss-out children from rural areas of Punjab. Further the study objective was to provide an in-depth exploration of the experiences of families who did not enroll their children in any school. The approach of the study was qualitative and participants were selected by considering the needs of the study. The study has provided useful insight and learning around the experiences of 25 families, across two districts of the Punjab; 13 families from district Multan and 12 families from district DG Khan were taken conveniently. An interview as data collection tool was used to get the data from children who are not going to school and their parents, and social workers of the community where they reside. The finding showed that poverty, education system, family's migrations due to rented homes, unemployment, low social status, teachers' attitude towards students, lack of skill-based curriculum, orphan hood, social and cultural pressures contribute to the student miss.
\end{abstract}

Keywords: Miss-out children, Education, literacy rate, Out of School children Introduction

Getting education is the basic right of every citizen in Pakistan but $44 \%$ children are not enrolled in any formal or non-formal school (Statistics, 2013). Under the Article 25A "the state shall provide free and compulsory education to all children of the age of five to sixteen years in such manner as may be determined by law" (Act, 2010). Pakistan's overall literacy rate is only 67\%. However, 44\% children out of $33 \%$ illiterate have never been enrolled in any type of school. I will use 'miss out children' in the study for the children who neither enrolled in any type of school nor receiving education other than at school such as at home and such type of children are 22.6 million in Pakistan which is the highest proportion in South Asia (Alif Ailan, 2017). However it is the responsibility of state in preventing children missing education. Pakistan is a signatory of Dakar declaration but still far-flung to achieve the Dakar Framework goals. According to the report presented by Fayaz Ahmad 'Pakistan to Education Task force' states that "roughly one in ten of the world's primary-school-age children who are not in school live in Pakistan" (Aljazeera, 2011).

On the other hand, the situation in Pakistan is improving and "the number of out-of-school children in classes 1-12 and the age bracket of 5-16 years has reduced by 3\% per annum from 25.96 million in 2012-13 to 22.64 million in 2015-16. Punjab has outperformed other provinces by managing to reduce the number by $6 \%$ per annum from 12.87 million to 9.92 million during the same period," (Kashif, 2017).

As said earlier it is the duty of government to bring out of school children towards education by providing opportunities and launching different schemes. It is important to notice that giving education is necessary not just attending schools. So government can facilitate out of school children by taking many initiatives which may be in form of providing schooling at the place convenient to learners and starting of different shifts in schools so that those who earn bread for their families in the morning may attend the school in the evening and vice versa..

\footnotetext{
${ }^{1}$ Section 9 of the Constitution (Eighteenth Amendment) Act, 2010 (10 of 2010), inserted a new Art. 25A, after Art. 25 of the Constitution, (w.e.f. April 19, 2010).
}

* University of Education, Lahore Email: qaisarshahzada@ yahoo.com
** University of Education, Lahore Email: ib@ue.edu.pk
*** Kinnaird College for Women Jail Road Lahore Email: shirazmaria@ gmail.com 
Government has already taken a few initiatives to cope this issue and is contributed a lot to bring out of school children to school but there is always room for improvement and need to do more. Government can improve their procedures and initiatives if it comes to know the actual reason/factors behind missing out children. So there is need to explore the actual reasons of out of school children from rural areas of Punjab. Many researches have been conducted on this issue but no contextspecific evidence is available to confirm and rank the causes of school miss out. Moreover, there is no much literature available on causes of miss out children from schools and the solutions to the issue. However, some factors related to out of school children are highlighted in various studies and reports, but still it remains one of the biggest challenges for Pakistani government. By considering all these challenges the current study is designed to explore the reasons for non-enrolment of children at school. For the current study the conceptual framework would cover the following main areas/themes which are recommended and studied in-depth by different studies carried out on the subject including the study done by Hoppers (2006) under International Institute for Educational Planning, UNESCO (2010).

- $\quad$ Personal reasons related to students (lack of motivation, interest, family and health issues etc.)

- $\quad$ Socio-cultural constraints (gender bias, early marriages, orphan hood etc.)

- Economic dimensions of non-formal schooling (poverty, access and engagement issues, cash support etc.)

- $\quad$ Costing of non-formal schooling on students/learners/adults

- $\quad$ Process and dynamics related to design and establishment of non-formal centers/schools

- Community mobilization issues (how the benefit of non-formal education is positioned within local, social, cultural and economic context, school-community interaction)

- $\quad$ Curriculum and pedagogical practices and its relevance to economic, social and cultural needs

- $\quad$ Outcome and achievement of non-formal schooling in comparison to formal

- $\quad$ Status, role and support of teachers and supporting staff

- $\quad$ Inter and Intra department relationship

- $\quad$ Relationship between non-formal education providers and parents.

In this regards the current study was conducted to insight the causes of miss out children from schools. This study is expected to bring out more productivity in operations of Government of the Punjab as far out of school children are concerned. This research study has been carried out, to generate information on main reasons of out of school children and to offer informed recommendations and appropriate measures to address them.

\section{Study Objectives}

This study has specifically achieved the following objectives:

1. To identify causes of miss out of primary level and adult/adolescent learners

2. To identify barriers in adult illiterates' motivation toward attaining basic education and learning

\section{Methodology}

\section{Setting and Participants}

The approach of the study was qualitative and participants were selected by considering the needs of the study (Richards \& Morse, 2012). We focused on in-depth, descriptive information from parents of the student who got enrolled in a school, non-enrolled children, and social workers. The sample of the study, taken conveniently, from two districts of the Punjab: Multan and DG Khan The sample distribution is presented in table 1.

Table 1

Study Sampling: Parents, Children and Social Workers

\begin{tabular}{llll}
\hline Districts & Parents & Children & Social Worker \\
\hline Multan & 13 & 13 & 5 \\
DG Khan & 12 & 12 & 5 \\
Total & $\mathbf{2 5}$ & $\mathbf{2 5}$ & $\mathbf{1 0}$ \\
\hline
\end{tabular}

\section{Piloting - Testing Instruments}

The piloting took place for a week which not only helped to frame the structure of the main study but also facilitated to refine our thinking about the research, methodology, and tool used for example interview questions. Piloting helped to review the questions, to eliminate ambiguities and differences 
in wording and to see whether the questions were generating the required information. The following are the pilot study respondents.

\section{Table 2}

Sampling for piloting of miss out students

\begin{tabular}{llll}
\cline { 1 - 1 } S. No & Location Lahore (Shahdara) & No. of Respondents \\
\hline $1-$ & Non-enrolled children & 2 \\
$2-$ & Parents of missing Education children & 2 \\
$3-$ & Social Workers $\quad$ Total Respondents $=$ & 6 & 2 \\
& &
\end{tabular}

Piloting revealed that the study objectives are worth exploring and elicited sufficiently rich data. The study respondents; parents, children and social workers behaved positively and were not reluctant to share their experiences and views. Although, it was felt that female research assistants would be helpful to get access to female teachers and parents. Pilot study informed about few real issues including access to miss out children. It was hard to access the miss out children since they did not have permanent accommodation. It is also noted that snow-ball sampling technique would prove more helpful in getting access to the miss out children. Interview protocols works well so there was no need of revision or change of questions but sequence of questions may be different according to the respondents' experiences. It was realized that more probes and prompts would be more helpful to clarify the context and to obtain more information from the respondents.

\section{Data Collection}

Interviews: Interviews were conducted with 25 families (parents) where children were currently missing schools and appeared not to be on a school roll and 25 children of these families (we included those who gave consent). These families provided retrospective comments on their experiences. To meet our research objectives, we interviewed 10 social workers. Our interviews with children were designed to be in child-friendly environment with options to draw out a pathway and label this with drawings, where appropriate. A breakdown of families interviewed is shown in Table 1. Researchers conducted semi-structured individual interviews with the miss out children parents and miss out children to know their views why children are not going to any schools. These interviews provided data on the views of students and their parents that why they were never enrolled in a school.

The interviews varied in length depending upon the disposition of the interviewee; the length ranged between 15-20 minutes. All the interviews were audio recorded and permission was sought from all the respondents before recording. The data were analyzed to identify common recurring themes.

Developing Interview Guide: The data were collected though semi structured interview. Interviews were carried out with the assumption that perceptions, experiences, challenges and suggestions of the respondents could be explored in detail. Interviews also provided the opportunity to follow up issues emerging from the responses. An interview guide was developed, which covered the key areas and issues relevant to the purpose of the study mentioned earlier. Within different overarching areas there were several sub questions that were intended to open up the conversations.

\section{Analysis of the Data}

All the interviews were audio-taped and analyzed after transcription. Interviews were conducted in Urdu and notes were taken at the same time. Punjabi was also used with parents for their convenience to talk freely. Following steps were followed for the analysis of data.

First stage was data reduction which helped in selecting, summarizing, coding and sorting data into themes, clusters and categories. For systematic analysis respondents' responses were arranged according to the interview guide. At the same time, attempt was made not to lose the meaning and context of the respondents. In few instances, whole paragraph/ conversation was added with particular responses to present more explicit and contextualized information. At this stage a deductive, top-down, or a priori approach was used for generic classification of responses.

Second stage involved conceptual interpretation. It was inductive, bottom-up, or a posteriori approach. The general themes were identified by the carefully examining the responses which facilitated in meaning making of the data.

In last stage, conclusion was drawn while interpreting and giving meaning and explanation to data. 


\section{Findings/Results}

The main aim of the study was to identify the reasons of miss out and to elicit information on barriers and challenges of miss out including the nature and issues of classroom and pedagogical practices. The following sections present causes of miss out children analyzed by (a) parents (b) school children and (c) social workers.

\section{Causes of miss out as perceived by parents}

Parents of the miss out children were identified as the primary source of information to identify the reasons and challenges of miss out. Twenty five parents from two districts in total i.e. 13 from Multan and 12 from DG Khan were approached who were not sending their children to schools. We divided the information according to key areas identified in the questionnaire. Socio-economic background of each family by each district is given in Table 3 :

Table 3

Families socio-economic status: Multan

\begin{tabular}{|c|c|c|c|c|c|c|c|c|c|}
\hline $\begin{array}{l}\text { Respondent } \\
\text { Name }\end{array}$ & $\begin{array}{l}\text { Total } \\
\text { Number } \\
\text { of } \\
\text { children }\end{array}$ & $\begin{array}{l}\text { Non- } \\
\text { enrolled } \\
\text { children }\end{array}$ & $\begin{array}{l}\text { Distance } \\
\text { School } \\
\text { to Home } \\
(\mathrm{KM})\end{array}$ & $\begin{array}{l}\text { Father } \\
\text { Education }\end{array}$ & $\begin{array}{l}\text { Mother } \\
\text { Education }\end{array}$ & Occupation & $\begin{array}{l}\text { Other } \\
\text { source } \\
\text { of } \\
\text { Income }\end{array}$ & $\begin{array}{l}\text { Average } \\
\text { Monthly } \\
\text { income }\end{array}$ & $\begin{array}{l}\text { House } \\
\text { Own/Rented }\end{array}$ \\
\hline $\mathrm{R} 1$ & 4 & 1 & 5 & *UE & UE & Laborer & No & 60000 & Own \\
\hline $\mathrm{R} 2$ & 2 & 2 & 2 & UE & UE & Laborer & No & 13500 & Own \\
\hline R3 & 6 & 4 & 1 & UE & UE & Laborer & No & 25000 & $\begin{array}{l}\text { Owner's } \\
\text { house }\end{array}$ \\
\hline $\mathrm{R} 4$ & 4 & 4 & 1 & UE & UE & Laborer & No & 15000 & No house \\
\hline R5 & 4 & 4 & $1 / 2$ & UE & UE & Laborer & No & 15000 & No house \\
\hline R6 & 3 & 3 & 2 & $\mathrm{UE}$ & UE & Laborer & No & 13000 & Own \\
\hline R7 & 2 & 2 & $2-3$ & Primary & UE & Laborer & No & 10000 & Rented \\
\hline $\mathrm{R} 8$ & 6 & 1 & 2 & UE & UE & Laborer & No & 21000 & $\begin{array}{l}\text { Owner's } \\
\text { house }\end{array}$ \\
\hline R9 & 2 & 2 & 4 & UE & UE & Laborer & No & 21000 & Rent \\
\hline R10 & 4 & 1 & 4 & UE & UE & Laborer & No & 36000 & $\begin{array}{l}\text { Owner's } \\
\text { house }\end{array}$ \\
\hline R11 & 5 & 5 & 1 & UE & UE & $\begin{array}{l}\text { Work on } \\
\text { daily } \\
\text { wages }\end{array}$ & No & 9000 & Cottage \\
\hline $\mathrm{R} 12$ & 8 & 8 & Nearby & UE & UE & $\begin{array}{l}\text { Plastic } \\
\text { goods }\end{array}$ & No & 12000 & Cottage \\
\hline R13 & 2 & 2 & Nearby & UE & Primary & Laborer & No & 6000 & Rent \\
\hline
\end{tabular}

Table 4:

Family socio-economic status: DG Khan

\begin{tabular}{llllllllll}
\hline $\begin{array}{l}\text { Respo } \\
\text { ndent } \\
\text { Name }\end{array}$ & $\begin{array}{l}\text { Total } \\
\text { Number } \\
\text { of } \\
\text { children }\end{array}$ & $\begin{array}{l}\text { Non- } \\
\text { enrolled } \\
\text { children }\end{array}$ & $\begin{array}{l}\text { Distance: } \\
\text { School to } \\
\text { Home } \\
\text { (KM) }\end{array}$ & $\begin{array}{l}\text { Father } \\
\text { Education }\end{array}$ & $\begin{array}{l}\text { Mother } \\
\text { Education }\end{array}$ & Occupation & $\begin{array}{l}\text { Other } \\
\text { source } \\
\text { of } \\
\text { Income }\end{array}$ & $\begin{array}{l}\text { Average } \\
\text { Monthly } \\
\text { income }\end{array}$ & $\begin{array}{l}\text { House } \\
\text { Own/Rented }\end{array}$ \\
\hline S1 & 8 & 8 & Nearby & UE & UE & $\begin{array}{l}\text { Begging } \\
\text { Plastic } \\
\text { goods }\end{array}$ & $\begin{array}{l}\text { No } \\
\text { No }\end{array}$ & $\begin{array}{l}90000 \\
75000\end{array}$ & Cottage \\
Cottage
\end{tabular}




\begin{tabular}{|c|c|c|c|c|c|c|c|c|c|}
\hline S8 & 4 & 1 & 2 & UE & UE & Laborer & No & 21000 & $\begin{array}{l}\text { Owner's } \\
\text { house }\end{array}$ \\
\hline S9 & 2 & 2 & 4 & UE & UE & Laborer & No & 21000 & Rent \\
\hline S10 & 4 & 1 & 4 & UE & UE & Laborer & No & 36000 & $\begin{array}{l}\text { Owner's } \\
\text { house }\end{array}$ \\
\hline S11 & 4 & 2 & 1 & UE & UE & $\begin{array}{l}\text { Daily } \\
\text { wages }\end{array}$ & No & 9000 & Cottage \\
\hline $\mathrm{S} 12$ & 3 & 1 & 2 & UE & UE & Laborer & No & 21000 & $\begin{array}{l}\text { Owner's } \\
\text { house }\end{array}$ \\
\hline
\end{tabular}

Parents of miss out children are uneducated and their occupation is laborer or working on daily wages. Their earning is below the line of poverty except two, one of them is beggar and other is doing his own business. The average number of children of each family is 4 but few families have more than of 8 . However, more than 80 percent of the children of sampled families were not going to school.

\section{Causes of Miss out as Perceived by Parents}

The following section talks about the parents views of two districts of Punjab, why they are not sending their children to schools.

\section{No Permanent Source of Income}

Analysis of interviews data shows that one of the reasons for missing out of children was the parents of such children had no permanent source of income. Parents earning was erratic therefore, they avoid sending their children to schools. They thought that sending children to school was a continuous addition to their expenses. Since evidence shows (see tables $3 \& 4$ ) that occupation of parents of such children from both districts were laborers or baggers or workers on daily wages. They had no permanent source of income.

\section{Poor Economic Condition}

Poor economic condition is another reason that stops children from enrolling in school. Parents shared that poverty forced them to send children to work rather schools. Mostly elder from the family go for work to meet the basic needs of the all members of the family and the member having school going age stay at home to take care of very young siblings. As one of the parents said, "we don't have enough money, madam. We hardly bear our basic expenditures. Nothing happens. It is very important to feed yourself by doing labour on daily basis... If the government helps us ..., then we will be happy to enroll our children in non-formal school otherwise............."

\section{Supporting Parents in Labor}

Child labor is also a significant factor that cause of miss out children from school. The data show that most parents prefer to send their children after reaching the age of 10 for making money other than going to school. This is a very serious issue noted in both districts. Children support their parents in their earnings for living and therefore they are involved in many activities like farming, hawking and trading. As a result they do not go to school. Moreover, they believe that earning/money making is a ultimate objective which can be achieved either by going to school or without going to school. Similarly mostly mothers involve their daughter in household activities.

\section{The System of Education not addressing the Societal Needs}

Another cause of concern is the relevance of education. Parents think that their children could not learn any useful or income generating skills at school. They were of the view that general education has no scope and did not help them for earning. However, they were willing to send their children to school if schools provided technical skills rather general education and had no financial burden for them.

\section{Unacceptability of Non-Formal Schools by Parents}

Another reason parents put forward for not enrolling is the unacceptability of non-formal school. Parents were found interested to send their children in private schools rather formal and non-formal schools. Parents recommended that accessibility of education must be provided in rural areas so that they can send their girls without any safety concern. As one of the parents said I am not interested to enroll my child in non-formal school, although it is very near to my home. In the response of researcher's probing he said I do not think "non-formal school could provide education while gathering all grade of students in one room and similarly there is no proper education in government schools". 


\section{Indirect Cost of Education}

Non-formal schooling is facilitating families in direct costs which include the payment of school fees, purchase of uniforms, and school bag, school mat etc. Therefore, it is reasonable to assume that household income would not be a major barrier in sending school to children. However, this correlation does not necessarily imply causation. On the other hand indirect costs include the opportunity cost of a child's time - a child could be earning an income rather than spending time at school, so this implies the household is losing income by educating a child are forcing many children to miss out from school or preventing them from getting an education. As one of the families said "... is not the only expenses in education... there are many more things that should be necessary during education for example, uniform should be neat and clean every day and children demand money on daily basis etc .... It is my hard wish that my children should get education but.... my income does not allow. ...".

\section{Health Issues}

Some families had health issue so the major chunk of their earnings was spending on their medicines. So they did not have other sources to meet the expenses of their kids for education. For example one of the mothers said: "We are poor people, my husband and one of my daughters are heart patient. A major chunk of income spent on their medicine... we are poor, and it is difficult to afford education expenses....... ${ }^{\circ} .$. my youngest daughter has left the school .... [weeping] ...."

We cannot generalize above odd case to all the families but poverty was reality in their home which may give birth to such issues. The study also found out that there is a negative perception many parents of these children with disabilities often do not send their children to school.

\section{Frequent Parental Migration Moving Home}

Keeping in view the labour work available the parents move from one place to the other places for agricultural labor (seasonal, industrial labor and etc.). We spoke to a number of families who moved house (sometimes repeatedly). For some, this contributed to their children missing out schooling. Moving home led to particular problems e.g. when families moved to new area where there was pressure on earning avenues, which cause of their children missing out of schooling. "We don't have permanent residence so we cannot take risk of our children education because today we are here and we do not know about tomorrow".

In the response of the question who can support you? They thought that government should support them. They were of the opinion:

"If government supports us then they would be in a position to send our children to the schools. The government should first make sure that the already educated people get their due share of employment according to their qualification. Then it will create more room for the uneducated people to get education and pursue promising jobs for them as well. The government should give everyone a job security; that whoever gets education will get a job at every cost".

\section{Uneducated Parents}

Illiteracy on the part of parents and lack of awareness of the prospective benefits of education prevent some parents from sending their children to school.

\section{Causes Shared by out of School Children}

Keeping in view the purpose of the study, views of the missed-out children were pivotal. Twenty five missed-out children (see table 1) were approached who shared their views about the reasons of miss out and barriers in continuation of their schooling.

\section{Unawareness of Free Education}

Almost all children shared that they did not know that Education is totally free either in non-formal schools or formal schools.

\section{Take Care of Siblings}

Children also indicated that sometimes when parents used to go to their work, the elder siblings had to take care of their younger siblings. For this reason, they cannot attend the school.

\section{Temporary Work}

Temporary nature of the parents' work was one of the reasons of miss out. Children shared that their parents had no permanent home, they had to move to different places to search for work which compel them to not joining of schooling. They also shared that sometime parents return home late after work which affects negatively to attend the school regularly. 


\section{Support from Government}

More than 50 percent children wished that they want to go to school if they were facilitated by government e.g. scholarship and financial incentives may be given. Moreover they shared that had to cope with a lack of educational opportunities and continued employment.

\section{Causes perceived by Social Worker}

The 10 social worker (see table 1) were also interviewed to further understand the causes of miss out children from schools. They shared the following points.

\section{Low Economic Background of Parents}

Lack of resources, low earning from parents, not having permanent jobs and temporary accommodation were the main barriers identified by social workers. Parents' illness and death are contributing factors towards discontinuation of children education.

\section{Lower Motivation}

Another other reason was the parents' and children interest and motivation towards education Interview analysis show that unemployment of parents or parents with fewer resources has less motivating to send their children to school. Ultimately they preferred to send their children to work instead of school.

\section{Passive Attitude of Parents}

Social workers identified the passive attitude of parents towards education which eventually resulted missing education. They do not care whether the child has gone to school or not. They think education cannot bring any immediate benefit for them and considered wastage of resources and time.

\section{More Issues}

Social worker raised a number of additional issues that might lead to a child missing education. These included:

- Mental health problems and associated difficulties with it prevented children to go to school. As one of the social workers said "children with disabilities are less likely to enroll and complete a full cycle of basic education. Mostly disable children were found to be out of school".

- $\quad$ Socials works observed that parents think that getting education is not as important to survive in society as earning some coins.

- $\quad$ Social workers stated that family issues, health issues, parents' drug and alcohol issues (addiction) are greater than making sure their son or daughter goes to school.

- Social workers shared that frequent migration of families for work is a big cause in their children continuation of their children education.

- $\quad$ Social workers thought some parents reached a point where they could no longer engage in the daily battle with their child to get them into school, so the child stopped going.

- $\quad$ Children who are orphans in most cases do not have any body to take care.

\section{Discussion}

Research from different developing countries specifically in Pakistan highlighted many obstacles in achieving of millennium goals. Out of school children is also economics driven issue in most developing countries where the majority of children work for survival and support their families. From very early age, mostly in villages, many children contribute to the monthly income by helping their families. As Roy (2000) stated financial and employment conditions of the families is one of the crucial factor in increasing the number of miss-out children. Job conditions are very poor in Pakistan; therefore, the families consider that sending the child to school means less household income coupled with rising expenses. Hussain, Salfi, \& Mahmood (2011) noted that the fear of parents specifically for girls to send school and accessibility are the hindrances in the way of literacy in Pakistan. They further added that the conditions prevailing in the schools are not satisfactory for the children or worrying their parents. In this study the main causes of miss-out children from schools highlighted by parents, children ansd social workers are poverty, education system is not addressing such families need; families mostly migrate from one place to other so no specific home and even they have no capacity to build their homes; unemployment and low social status. The studies (Hoppers, 2006; Hussain, Salfi, \& Mahmood, 2011; UNICEF, 2013; Ailaan, 2017; Ryder, Edwards, \& Rix, 2017) finding are aligned with our finding that school environment or community do not encourage the children missing their education to go to school. Further factors like poverty, teachers' attitude 
towards students, unviability of skill-based curriculum, orphan hood, social and cultural pressures i.e. children above a certain age are big hindrance in way of their school. Lack of adequate facilities, lack of appropriate courses and self-paced learning material, lack of community involvement are the reasons of out of school children.

The challenges resulted from low economic growth, growing poverty, low spending on education, growing cost on education to cover books, uniform and transportation fee, rented homes, sociocultural constraints (i.e. gender bias), lack of understanding about value of education contributed towards alarming high rate of dropouts and low retention from primary education in Pakistan.

\section{Recommendations}

From our research we have drawn the following recommendations.

- Special attention and incentives may be given to children belonging to poor families for convincing them to enroll their children in non-formal schools.

- Department may initiate different campaigns by engaging parents specially from poor families

- The number of non-formal schools should be increased in poor areas to increase the accessibility for out of school children.

- Quality of education at formal and non-formal school should be improved by; upgrading infrastructure i.e. improvement in school buildings, classrooms, latrines and water supply, desks and chairs, etc., increasing number of teachers, improving need based curriculum, providing opportunities for skill based learning, introducing more flexible hours and an increasing salaries of teachers.

- $\quad$ Children and parents may be involved in decisions making around education to increase their engagement.

\section{References}

Ailaan, A. (2017) Million Broken Promises: The crisis of Pakistan's out-of-school children. Alif Ailaan, Islamabad: ISBN 978-969-23023-0-2. https://d3n8a8pro7vhmx.cloudfront.net/ alifailaan/pages/540/attachments/original/142200998 8/Alif_Ailaan_report 25_million_ broken_promises. pdf.

Hoppers, W. (2006). Non-Formal Education and Basic Education Reform: A Conceptual Review: Paris: IIEP, UNESCO .

Hussain, A., Salfi, N., \& Mahmood, T. (2011). Causes of students' dropout at primary level in Pakistan: An empirical study. International journal of humanities and social science, 1(12), 143-151.

Kashif Abbasi "22.6m Pakistani Children Still out of School: Report." DAWN.COM, 9 Mar. 2017, www.dawn.com/news/1319300

Richard, L., \& Morse, J. (2012). Readme first for a user's guide to qualitative methods: London: Sage.

Roy, R. (2000). Child labor, child schooling, and their interaction with adult labor: empirical evidence for Peru and Pakistan. The World Bank Economic Review, 14(2), 347-367.

Ryder, R., Edwards, A., \& Rix, K. (2017). Children missing education. Seced, $\quad 2017(12), 12-12$.

Statistics, P. E. (2013). National Education Management Information System NEMIS: Academy of Education Planning and Management AEPAM. Government of Pakistan.

UNESCO (2010). Access to Secondary Education. Bangkok: UNESCO Asia and Pacific Regional Bureau for Education.

UNICEF. (2013). Out-of-school children in the Balochistan, Khyber Pakhtunkhwa, Punjab and Sindh provinces of Pakistan. Islamabad, Pakistan: UNICEF Pakistan. 